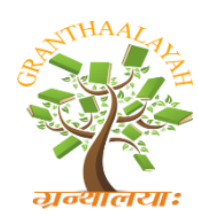

INTERNATIONAL JOURNAL OF RESEARCH GRANTHAALAYAH A knowledge Repository

Social

\title{
RELEVANCE OF MID DAY MEAL PROGRAMME WITH SPECIAL REFERENCE TO LOCAL BODY SCHOOLS OF DURG AND BHILAI TOWN
}

\author{
Rashmi Tiwari *1 \\ ${ }^{* 1}$ Guest Faculty, Kushabhau Thakre Patrakarita Avam Jansanchar Vishwavidyalaya, Raipur
} (CG), India

DOI: https://doi.org/10.29121/granthaalayah.v5.i4.2017.1819

\begin{abstract}
In India illiteracy is one of the major problems of Indian society. There are many programmes/schemes/projects are run by the central and state governments which meant to increase in literacy. Therefore Mid-day meal programme was introduced in 1995 with one of the aim to increase in enrollment of children in primary schools. In many evaluative studies of MDMP by the government, it is claimed that enrollment of children has increased drastically and still it is one of reasons for increase in enrollment. To evaluate the programmme, that still after more than 20 years when socio-economic scenario of the Indian society has changed the, MDMP is still equally relevant and effective for increase in enrollment, the researcher is selected 10-10 local body schools of Durg and Bhilai towns. In local body schools of Durg a women Self Help Group "Sakhi Saheli" has been supplying the cooked food while in Bhilai "Akshay Patra Foundation" has been supplying meal. 10 children from 5th to 8th standard have been selected from each school. The primary tool of data collection is an Interview schedule. Data analysis showed that most of the children are willing to come to school even if government would have discontinue MDMP i.e. it is no longer the reason for increase in enrollment and regular attendance in schools.
\end{abstract}

Keywords: Mid-Day Meal Programme; Meal/Food; Enrollment; Attendance.

Cite This Article: Rashmi Tiwari. (2017). "RELEVANCE OF MID DAY MEAL PROGRAMME WITH SPECIAL REFERENCE TO LOCAL BODY SCHOOLS OF DURG AND BHILAI TOWN." International Journal of Research - Granthaalayah, 5(4), 263-267. https://doi.org/10.29121/granthaalayah.v5.i4.2017.1819.

\section{Introduction}

The Government of India was launched Mid-Day Meal Programme on 15 August 1995 as National Programme of Nutritional Support to Primary Education in 2400 blocks of the country with the aim to encourage universal primary education. In 1997-98 the programme was extended 
to all blocks and 2001 onwards it became universalized after Supreme Court order. In the year 2007, the programme included students of upper primary classes of 6th to 8th standard. The main objectives of Mid-day meal programme are to increase school enrollment and attendance, to avoid classroom hunger so children can concentrate on studies, to address malnutrition by providing nutritional support. Therefore children of upto primary classes have been provided with 450 calories and 12 grams of protein and of upper primary classes have been provided with 700 calories and 20 grams of protein. Central government provides $75 \%$ of the cost and free food grains to states. Since 1995 the enrollment and literacy rate has increased. Due to change in socio-economic status, thanks to various governmental schemes, it is necessary to assess the relevance of MDMP especially for enrollment and attendance in schools after more than 20 years of its launching. Local body schools of Durg and Bhilai towns of Chhattisgarh State has selected for the study.In schools of Durg a women Self Help group " Sakhi Saheli " has been supplying cooked food and In Bhilai, Bhilai Steel Plant sponsored "Akshay Patra Foudation" (APF) has supplying meal under its Corporate Social responsibility. The APF is a charitable trust, serving around 160 schools in and around Bhilai through its centralized kitchen.

\section{Significance of the Study}

The government provides crores of amounts to the programme so it is necessary to assess its relevance.

\section{Objectives of the Study}

1) To assess the relevance of MDMP especially in terms of enrollment and attendance of the children.

2) To find out changes required in the programme.

\section{Hypothesis}

1) Mid-day meal Programme motivates children to enroll in schools.

2) Mid-day meal programme ensures regular attendance of children in schools.

3) Mid-day meal programme does not ensure increase in enrollment and attendance in schools in current socio economic scenario of the country.

\section{Review of Literature}

A large body of literature available on MDMP. Studies on various parameters of MDMP were conducted at national and state level. According to Dre'ze and Goyal (2003) the achievements of MDMP depends on the quality. Parikh and Yasmeen (2004) and Josphine and Raju (2008) found that the public private partnership model of implementation of MDMP could do much better on the basis of the study of working of Nandi foundation in Hyderabad, ISKON in Bangalore. Anuradha, Noronha and others (2005) in Delhi showed that quality and hygiene of the food was not up to the mark and NGOs involved make the programme a business venture. Afridi (2005) found in Madhya Pradesh that 35\% of the households dissatisfied with the MDMP due to poor taste. Dr. Daniel, Garg and others found no prescribed menu is followed in Durg district besides lack of hygiene, low quality of food. In Chhattisgarh a comprehensive evaluative 
study on the status of MDMP in primary schools, done by AIDE ET ACTION - South Asia (2008). One of the finding was the quality of foo was below the stipulated norm. Result of study on the impact of MDM on enrollment and retention of children in schools, done by Sailja Singh and Nisha Gupta (2013) revealed that the scheme prove a major mean in improving enrollment and attendance.

\section{Limitations of the Study}

1) The study is limited to local body schools of town areas of Durg and Bhilai towns. It does not reflect the opinions of children of government schools of village area.

2) The study does not include the opinion of parents/guardians of children.

\section{Research Methodology}

To conduct evaluate type of study for Mid-day meal programme the local body schools of twin towns of Durg and Bhilai of Chhattisgarh were selected to collect the primary data. Proximity to the researcher and two different agencies involved in supplying MDM are reasons behind selection of the study area, as quality of food supplying by different agencies may influence the view of children regarding MDM.10 -10 students of 5th to 8th standards each from 10-10 schools of Durg and Bhilai are taken by simple random sampling. The size of the sample is 200 children. Primary source of data - school children of 5th to 8th standards. Conversations with teachers, head masters/mistress also provides valuable information. Secondary source are annual reports, books etc. Interview Schedule was prime source of data collection which contains 14 items. Some of the important contents are -

1) Occupation of the parents of children/economic status of the family of children.

2) Whether Mid-day meal an important factor to take admission in school.

3) Whether Mid-day meal ensures daily attendance of children.

4) Prefer to bring lunch box or take meal in schools.

5) Satisfaction with quality of food.

Conversation with teachers and Head master/mistress has also confirmed the opinion of children. One of Head master of Durg School has informed that a lot of food wasted daily as children do not take food. Most of the teachers of schools of Durg town have of opinion that students don't want to take mid-day meal because of its poor quality and government should provide fruits and vegetable instead. Some teachers of Bhilai schools said even mid-day meal is of good quality, government should improve the programme as they have to insist children to take meal.

\section{Tabulation and Analysis of Data}

The collected data after classification shows following results -

\begin{tabular}{|l|l|l|l|l|l|l|}
\hline Parameters & \multicolumn{3}{|l|}{ Responses of Durg (in \%) } & \multicolumn{3}{l|}{ Responses of Bhilai (in \%) } \\
\hline & Yes & No & $\begin{array}{l}\text { Don't } \\
\text { Know }\end{array}$ & Yes & No & $\begin{array}{l}\text { Don't } \\
\text { Know }\end{array}$ \\
\hline Enroll in schools due to MDM & 2 & 95 & 3 & 3 & 97 & 0 \\
\hline $\begin{array}{l}\text { Regular attend school due to } \\
\text { MDM }\end{array}$ & 1 & 96 & 5 & 3 & 96 & 1 \\
\hline \hline
\end{tabular}




\begin{tabular}{|l|l|l|l|l|l|l|}
\hline $\begin{array}{l}\text { Satisfaction with the quality of } \\
\text { food }\end{array}$ & 20 & 63 & 77 & 8 & 15 \\
\hline Prefer to bring lunch box & 64 & 36 & 0 & 16 & 82 & 2 \\
\hline
\end{tabular}

1) Most of the children belong to low income family. Their parents or one of the parents are working as motor mechanics, rickshaw pullers, vegetable vendors, fruit vendors, carpenters, house helpers etc.

2) $97 \%$ of students of Bhilai and $95 \%$ of students of Durg town agreed that they will come to school daily, even if government would have discontinue the Mid-day meal.

3) Upto $40 \%$ of the children of schools of Durg have been taking mid-day meal, but in Bhilai more than $80 \%$ children have been taking meals. Because children of schools of Bhilai are satisfied with quality and menu of the food supplied by Akhshay patra foudation. $77 \%$ of the children of schools of Bhilai are satisfied with quality of the food as compare to $17 \%$ in case of Durg.

4) Very few children bring their lunch box, because in schools of Bhilai "Akshay Patra Foudation" has been supplying good quality of food and in schools of Durg most of the children neither take mid-day meal nor they bring their lunch box.

\section{Conclusion}

It is clear that most of the students who belong to low income families, come to schools not because of Mid-day meal and they agree to come to school even if the programme would have been discontinued by the government. It can be said, now MDMP does not motivate children to enroll in schools and also it does not ensure their regular attendance. This fact is clearer in Durg schools where only up to $40 \%$ students have been taking Mid-day meal but they come to school regularly. The reason behind such change in view of children regarding education is increase in awareness for the same. Also hunger is no longer common in the country as it was before 1990s.MDMP should be continued in improved form.

\section{Suggestions}

1) It is required to include children from schools of village as their opinion may defer from children of urban schools, because socio-economic scenario of villages is different from urban areas.

2) It is necessary to reform the programme and should include fruits and milk in place of food grains to make it more relevant.

\section{References}

[1] Sikligar P.C., Mid Day Meal Scheme and School Education, Concept Publication,2011

[2] Pandey Manoj, Mid Day Meal Programs in Schools, LAP LAMBERT ACADEMIC Publication

[3] Kumar Ranjit, Research Methodology : A Step by Step Guide for Beginners , 2nd Edition Pearson (2005)

[4] Mid Day Meal Programme - Annual Work Plan and Budget , 2012-13

[5] AIDE ET ACTION - South Asia Report on Mid day meal (2008) 
[6] Josphine and Raju,(2008)." A study of Best Practices in the Implementation of Mid Day Meals Programme in Andhra Pradesh". http://www.educationforallinindia.com/best-practices-mid-daymeal-in-andhra-pradesh-by\%20joshpine-yazali.pdf

[7] Singh Sailija, and Gupta Nisha (2015). "Impact of Mid Day Meal on Enrollment, Attndance and retention of primary School Children". International Journal of Science and Research. Vol. 4, Issue 2.

[8] Dre'ze, and Goyal.(2003)."Future of Mid Day Meals". Economic and Political Weekly. Vol. 38, Issue No.44.

[9] Anuradha,Noronha, and Others.(2007)."Towards More benefits from Delhi's Mid Meal Scheme". Sage Publication

[10] Afridi Farzana.(2005). "Mid Day Meals in Two States". Economic and Political Weekly. Vol. 40, Issue No. 15

[11] http://www.cg.nic.in/eduportal/Schemes/MDM_Detail.aspx

[12] http://mdm.nic.in/

[13] https://www.akshayapatra.org/indias-mid-day-meal-scheme

*Corresponding author.

E-mail address: rashmitiwari25@gmail.com 